\section{Who's hiding primary data?}

\section{Washington}

THE International Union of Crystallography (IUC) this month published a policy statement urging scientific journals to ensure that when researchers publish analyses of proteins, nucleic-acid and virus structures, they simultaneously make the primary data available, to allow independent verification of the results.

Increasing delays in the disclosure of primary data are causing heated debate in the crystallographic community and giving rise to accusations ranging from sheer sloth to unjustified suppression of data obtained through publicly funded research.

The standard way to provide the primary data is through the deposition of the structure's atomic coordinates in the protein databank at Brookhaven National Laboratory. Many researchers believe that journals have a role to play in encouraging faster deposition of coordinates.

Last year, Frank Richards of Yale University wrote to several journals on behalf of almost 200 crystallographers urging them to "adopt and enforce" rules to make data more easily available. This would "ensure the preservation of important and expensively determined data which otherwise are likely to be lost". To

\section{GERMAN UNIVERSITIES}

\section{Green light for plan for young researchers Munich}

A PLAN to keep talented young researchers at universities received preliminary approval in West Germany last week.

Representatives of federal and Länder governments gave tentative approval to the plan, which would require an investment of DM6,000 million (about $\$ 3,060$ million) over ten years.

The plan, announced by Education Minister Jürgen Möllemann in May, is meant to prepare for an expected wave of retirements of university professors in the years 1995 to 2005 (see Nature 340, 252; 1989). Möllemann also plans to make funds specifically available to women in universities, where they have traditionally been under-represented.

As many as 5,000 young people would be supported in the programme's first year, and up to 50,000 would be supported at the end of the plan, said an Education Ministry spokesman.

Final approval will have to wait. A meeting originally scheduled for 21 September between Chancellor Kohl and the heads of the Länder at which the plan was to be discussed has been postponed because of Kohl's poor health. Steven Dickman satisfy researchers reluctant to release the data immediately, the databank could be instructed not to release the information until a specified date.

But the issue divides journals. The editor of Science, Daniel E. Koshland, $\mathrm{Jr}$, is willing to agree to these guidelines, but advocates a coordinated effort by all the relevant journals. The Journal of Biological Chemistry has strengthened its guide to authors to encourage deposition strongly. Others believe journals cannot act as 'watchdogs'. Nature's line is that there should be as few obstacles as possible between an author and publication. Some journals argue that granting agencies, for example, could require appropriate disclosure of data.

Even if journals agreed to require deposition of data in databanks, whether this should be done at the same time as publication of a paper is controversial. Some researchers argue that it takes several

\section{London}

A Row is brewing between the British government and conservation organizations over plans to split the the Nature Conservancy Council (NCC) across the national boundaries of England, Scotland and Wales. The proposals first surfaced in the summer, when Nicholas Ridley, then Secretary of State for the Environment, said the proposals were designed to "improve the way we handle conservation of wild fauna and flora and the countryside".

Ridley said that the "circumstances and needs" of England, Scotland and Wales are very different and that the present system of nature conservation are inadequate. The responsibilities of the NCC, which looks after nature conservation throughout Great Britain, and the two Countryside Commissions (CC), one covering England and Wales, the other Scotland, would be altered. The CCs are responsible for enhancing the natural beauty of the countryside.

The functions of the three bodies will be "exercised in future by separate bodies for England, Scotland and Wales", Ridley said. "The conservation and countryside functions should be the responsibility of a single body in each country." But the government intends that because of the density of population and the greater pressure on land in England, the NCC and CC there will be retained as separate bodies. The changes "require legislation which we shall bring forward at the earliest opportunity", Ridley added.

One of the more contentious issues will years of refinement before a structure is ready to be entered into a databank: Ken Holmes, of the Max-Planck Institute for Medicine, says it is "general practice to withhold coordinates ... and up to a point this is legitimate".

But Tom Steitz, of Yale University, sides with those who believe that if a structure is ready for publication, there must be data which can be released.

Steitz says the difficulty will be in finding some middle ground between those who call for immediate deposition of all data, even those not included in publications, and those who advocate a five- to ten-year time lapse while the structure is defined.

Rumours are now circulating in the crystallography community that researchers are selling coordinates to private companies instead of making them publicly available. Graham Derby of Wellcome says the debate is fuelled by a changing atmosphere in research, in which academics "are being encouraged to profit from anything that is potentially valuable".

Christine McGourty

\title{
Row ahead on conservation
}

be the future of the scheme for designating and conserving "sites of special scientific interest", at present the responsibility of $\mathrm{NCC}$; these range from habitats for valued animal and plants species to sites of geological or archaeological interest. Among other means of conservation, NCC administers a scheme for paying compensation to landowners for restraint in land exploitation, but more often the scheme has been resented (and even resisted) by those seeking to develop land.

The forthcoming debate will be an occasion when the British government will have further to define its plans for encouraging farmers to pay more attention to environmental considerations. But it is unlikely, at this late stage, that even those opposing the government's proposed reorganization will seek to put back the clock to when NCC had a research capability of its own, long since transferred to the Natural Environment Research Council.

But Sir William Wilkinson, chairman of NCC, says that the plans could "damage" the cause of conservation. He said conservation in Britain faces "complex challenges" and "mounting financial restraints" and that the proposals do nothing to help. "Wildlife issues are no respector of geographical or political boundaries", he said, while the separation would "undermine" the scientific capability of the NCC and "prevent effective policy advice being provided to government". In their present form the proposals would "weaken" the NCC's capacity to play a "co-ordinated and positive role".
Ben Webb 